\title{
The profile of low back pain disability on laborers at Kendari Port Southeast Sulawesi
}

\author{
Iriamana Liasyarah Marudin ${ }^{1}$; Muh. Rustam $\mathrm{HN}^{2}$; La Ode Alifariki ${ }^{3 *}$; Adius Kusnan ${ }^{4}$ \\ $1 *), 2,3,4$ Universitas Halu Oleo
}

\begin{tabular}{|c|c|}
\hline ARTICLE INFO & A B S T R A C T \\
\hline Article history: & $\begin{array}{l}\text { Low back pain is unpleasant or painful condition that can lead to } \\
\text { activity constraints. LBP is a major cause of disability in the }\end{array}$ \\
\hline Received May 15, 2019 & world. Based on data from the Port Health Office in $2018, L B P$ is \\
\hline Revised May 22, 2019 & a condition that is often experienced by porters in Kendari's Port. \\
\hline Accepted May 24, 2019 & $\begin{array}{l}\text { There are many factors that can affect lower back pain; such of } \\
\text { the following is smoking. This study aims to determine the }\end{array}$ \\
\hline Keyword: & $\begin{array}{l}\text { relationship between smoking degrees with disability of lower } \\
\text { back pain. This research was an observational analytic study with }\end{array}$ \\
\hline Low Back Pain & a cross-sectional approach. 130 samples were obtained through \\
\hline $\begin{array}{l}\text { Disability } \\
\text { Smoking Degree }\end{array}$ & total sampling. Data were analyzed using the Spearman \\
\hline *) corresponding author & $\begin{array}{l}\text { smoking habits } 70.8 \% \text { and mild disabilities } 42.3 \% \text {. Based on } \\
\text { statistical tests, a positive correlation between the degree of }\end{array}$ \\
\hline Jln.Prof.Dr.Abdurrauf Tarimana Kelurahan & smoking and disability of lower back pain was obtained in porters \\
\hline $\begin{array}{l}\text { Kambu Kota Kendari Prop.Sultra Asrama } \\
\text { Kabaresi }\end{array}$ & $\begin{array}{l}\text { in Kendari's port with } p \text { value }=0,000 \text { and a correlation } \\
\text { coefficient }=0.524 \text {. There is a significant relationship between }\end{array}$ \\
\hline Email: ners_riki@yahoo.co.id & $\begin{array}{l}\text { the smoking degrees and disability of low back pain in the porters } \\
\text { of Kendari's port. }\end{array}$ \\
\hline
\end{tabular}

DOI:https://doi.org/10.30604/jika.v4i2.197

\section{INTRODUCTION}

Musculoskeletal disorders suffered by hundreds of millions people that cause chronic pain and inflammation as well as disability or functional limitations, causing psychological and social disorders of patients, one of which is low back pain or low back pain which is the most common complaint among other pain complaints (WHO Scientific Group, 2003).
Low back pain is a condition that does not wear or chronic pain with complaints of at least 3 months accompanied by a limited activity caused by pain when moving or mobilizing (Helmi, 2013).

The functional abilities of LBP sufferers are related to daily activities, such as daily activities such as work, activities at home or 
activities in the office. Hobbies or sports activities, strenuous activities around the house, looking down, wearing shoes or 23 socks, lifting grocery boxes from the floor, sleeping, standing for 1 hour, walking 1 mile, going up or down stairs 20 steps, sitting for 1 hour, and drive for 1 hour.

Functional limitations or physical disabilities experienced by LBP sufferers can be categorized into 4 namely mild disability, moderate disability, severe disability and total disability.

LBP ranks highest in the world in terms of disability with a prevalence of $9.4 \%$. The number of LBP cases increased from 58.2 million in 1990 to 83.0 million in 2010. In addition, of the 291 diseases studied, LBP was the largest contributor to global disable measured through Years Lived with Disability (YLD) (Hoy, D ., March, L. \& Brooks, 2014).

Data for the number of LBP sufferers in Indonesia is still not known with certainty, but it is estimated that LBP sufferers in Indonesia vary between $7.6 \%-37 \%$ of the total population in Indonesia (Rohmawan, Eko Arma., Haryono, 2017). Research conducted by the PERDOSSI Pain Study Group (Association of Indonesian Neurologists) at 14 teaching hospitals in Indonesia, in May 2002 showed the number of pain sufferers was 4,456 people ( $25 \%$ of total visits), of which 1,598 people $(35.86 \%)$ is a LBP sufferer (Riningrum, Hanif., Widowati, 2016).

One of the factors related to LBP is smoking. The significant relationship between smoking habits and LBP complaints, especially for jobs that require muscle mobilization because nicotine in cigarettes can cause reduced blood flow to the tissues. Nicotine also contained in cigarette smoke can cause vasoconstriction of blood vessels.

Smoking can cause a decrease in perfusion and nutritional deficiencies in muscles and bones due to lack of blood flow to the tissues. In addition, smoking can also cause inefficient tissue to respond to mechanical stress, which can cause back pain complaints (Tveito, T.H., 2004).

In addition, smoking can also cause a decrease in mineral content in the bones, causing pain due to cracking or damage to the bone (Hadyan, 2015). In a study conducted by Sitepu et al (2015) on 32 citrus farmers in Dokan Village where there was a relationship between smoking and LBP (Sitepu D.S, Sinaga, 2015).

One of the highest risk groups is docker workers, because of the type of work that involves excessive activities such as lifting heavy objects. Especially this happened to the group of ship laborers, because transporting goods off the ship or vice versa was the goal of these workers. This is compounded by the habit of the workers consuming cigarettes. The results of a preliminary survey of workers in the port of Kendari indicate that dominant workers have poor smoking habits.

Smokers can be classified based on many cigarettes smoked per day. Bustan divided it into 3 groups, which said light smokers were smokers who smoked 1 - 10 cigarettes a day, moderate smokers, 11-20 cigarettes a day, and heavy smokers more than 20 cigarettes a day (Alifariki, 2015).

Based on the description above, the authors are interested in conducting research on the relationship between the degree of smoking and the disability of low back pain in loading and unloading labor in the Port of Kendari City. This is done because until now there has been no research using labor or port workers as respondents.

\section{METODE}

This type of research is observational analytic using cross sectional study design. This research was carried out in November to December 2018 at the Port of Kendari City and Koperasi Karya Bahari, Kendari City. The sampling technique used in this study 
was a total sampling of 130 respondents who met the criteria for inclusion and exclusion criteria.

Data collection was carried out by interviewing respondents using an identical questionnaire, Nordic Body Map (Shonafi $\mathrm{KA}$, 2012) to see whether there were complaints of low back pain and continued with the Oswestry Disability Index questionnaire (Jalajuwita, 2015) to assess the disability caused by low back pain experienced with the criteria of disability, mild, moderate, severe and total disability. Smoking risk assessment is divided into 3 groups, which said light smokers are smokers who smoke 1-10 cigarettes a day, moderate smokers, 11-20 cigarettes a day, and heavy smokers more than 20 cigarettes a day (Alifariki, 2015).

Data analysis was performed using the Spearmen statistical test with a p value $<0.05$ with the help of SPSS 16 (Arikunto, 2010). This research was approved by the Health Research Ethics Commission of the Institute of Research and Community Services at the University of Halu Oleo.

\section{RESULTS AND DISCUSSION}

Table 1 shows the results of research on the frequency distribution of research

Tabel 1

Distribusi frekuensi data penelitian components, including age, body mass index, work mass, work duration, degree of smoking and LBP disability among 130 respondents. The results of this study showed that in the 26-35 years age group were 26 people (20\%), aged $36-45$ years were 42 people $(32.3 \%)$, aged $46-55$ years were 54 people $(41.5 \%)$ and aged 56-65 years as many as 8 people $(6.2 \%)$. In the measurement of BMI, 13 people $(10 \%)$ were underweight, 65 people $(50 \%)$ were normal weight and 52 people $(40 \%)$ were overweight. Based on work mass, it shows that from the number of samples in this study as many as 130 people with a work mass of $\leq 13$ years a year as many as 23 people $(17.7 \%)$ and a work mass of> 13 years as many as 107 people $(82.3 \%)$. In addition, based on the length of work showed that as many as 64 people (49.2\%) with a length of work $<8$ hours and as many as 66 people $(50.8 \%)$ with a length of work $\geq 8$ hours. Based on smoking habits, respondents who have a degree of light smoking are as many as 92 people $(70.8 \%)$ and the degree of heavy smoking as many as 38 people (29.9\%) and also who do not experience disabilities as many as 43 people (33.1\%), mild disabilities were 55 people (42.3\%), moderate disabilities were 31 people $(23.8 \%)$, severe disabilities were 1 person $(0.7 \%)$ and none had total disabilities.

\begin{tabular}{|c|c|c|}
\hline Variable & Frequency & Percentage \\
\hline \multicolumn{3}{|l|}{ Age } \\
\hline $26-35$ year & 26 & $20 \%$ \\
\hline $36-45$ year & 42 & $32,3 \%$ \\
\hline $46-55$ year & 54 & $41,5 \%$ \\
\hline 56-65 year & 8 & $6,2 \%$ \\
\hline \multicolumn{3}{|l|}{ BMI } \\
\hline Lack of Weight & 13 & $10 \%$ \\
\hline Normal Weight & 65 & $50 \%$ \\
\hline Overweight & 52 & $40 \%$ \\
\hline \multicolumn{3}{|l|}{ Years of Service } \\
\hline$\leq 13$ Year & 23 & $17,7 \%$ \\
\hline$>13$ Year & 107 & $82,3 \%$ \\
\hline
\end{tabular}




\begin{tabular}{lcc}
\hline \multicolumn{1}{c}{ Variable } & Frequency & Percentage \\
\hline Work Period & & \\
$<$ 8 Hours & 64 & $49,2 \%$ \\
$\geq 8$ Hours & 66 & $50,8 \%$ \\
\hline Smoking Degrees & & \\
$\quad$ Mild Degree & 92 & $70,8 \%$ \\
$\quad$ Severe Degree & 38 & $29,2 \%$ \\
\hline Disabilities Level of LBP & & \\
$\quad$ Not disabled & 43 & $33,1 \%$ \\
$\quad$ Mild Disabilities & 55 & $42,3 \%$ \\
$\quad$ Moderate Disabilities & 31 & $23,8 \%$ \\
$\quad$ Severe Disabilities & 1 & $0,8 \%$ \\
\hline Total & 130 & $100 \%$ \\
\hline
\end{tabular}

The results of this research indicate that respondents who have mild degrees of smoking with no disabilities are 39 people $(30 \%)$, degrees of light smoking with mild disabilities are 46 people $(35.4 \%)$, mild smoking degrees with moderate disabilities are 6 people $(4,6 \%)$ and the degree of light smoking with a severe disability of 1 person $(0.8 \%)$ followed by the degree of heavy smoking with a disability of 4 people $(3.1 \%)$, the degree of heavy smoking with a mild disability of 25 people $(6,9 \%)$ and the degree of heavy smoking with moderate disability $(19.2 \%)$.

Based on this research, the highest presentation was found for respondents who suffer mild disabilities with a degree of smoking that is as many as 46 people $(35.4 \%)$.

Tabel 2.

Hubungan antara derajat merokok dengan disabilitas LBP pada TKBM di Pelabuhan Kota Kendari

\begin{tabular}{|c|c|c|c|c|c|c|c|c|c|}
\hline \multirow{3}{*}{ Merokok } & \multicolumn{8}{|c|}{ Disabilitas } & \multirow{3}{*}{$p$} \\
\hline & \multicolumn{2}{|c|}{ Tidak } & \multicolumn{2}{|c|}{ Ringan } & \multicolumn{2}{|c|}{ Sedang } & \multicolumn{2}{|c|}{ Berat } & \\
\hline & $\mathbf{n}$ & $\%$ & $\mathbf{n}$ & $\%$ & $\mathbf{n}$ & $\%$ & $\mathbf{n}$ & $\%$ & \\
\hline Derajat Ringan & 39 & $30 \%$ & 46 & $35,4 \%$ & 6 & $4,6 \%$ & 1 & $0,8 \%$ & \multirow{2}{*}{0,000} \\
\hline Derajat Berat & 4 & $3,1 \%$ & 9 & $6,9 \%$ & 25 & $19,2 \%$ & 0 & $0 \%$ & \\
\hline Total & 43 & $33,1 \%$ & 55 & $42,3 \%$ & 31 & $23,8 \%$ & 1 & $0,8 \%$ & \\
\hline
\end{tabular}

Based on the results of the statistical test analysis, the value of $p=0.001$ is obtained, which is a significant relationship because the value of $p$ is less than 0.05 . So it can be concluded that there is a significant correlation between the smoking degrees with LBP disability where the coefficient correlation value is 0.524 , which is a relationship with moderate power. There is a relationship between the two, $\mathrm{H}_{0}$ is rejected and $\mathrm{H}_{\mathrm{a}}$ is accepted.

\section{The Correlation of Smoking Degree with Low Back Pain Disability}

The results of this research are in line with research conducted by Lincoln (2003) regarding the correlation of smoking with musculoskeletal disabilities where the results show there is a correlation between the degree of smoking with musculoskeletal disabilities with LBP as the biggest disease in the musculoskeletal disorder section in this research. Heavy smokers have the highest cumulative risk of disability (17.6\%), followed by moderate smokers $(15.8 \%)$, nonsmokers $(12.2 \%)$ and then ex-smokers (10.3\%) (Lincoln, Smith, Amoroso, \& Bell, 2003). In addition, another research conducted by Prasarn (2012) showed that there was a significant correlation between smoking history and LBP disability measured using the Oswestry Disability Index (ODI) 
where the worst ODI scores were reported by smokers at this time $(44.33 \%)$, followed by previous smokers $(38.11 \%)$, and finally by nonsmokers $(36.02 \%)$ (Prasarn, Mark L., Horodyski, Mary B., Behrend, Caleb., Wright, John., Rechtine, 2012).

Significant correlation between smoking habits and LBP complaints, especially for jobs that require muscle mobilization because nicotine in cigarettes can cause reduced blood flow to the tissues. In addition, smoking can also cause a decrease in mineral content in the bones, causing pain due to cracking or damage to the bone (Hadyan, 2015).

The nicotine content in cigarettes causes vasoconstriction of blood vessels that supply nutrients to intervertebral disc cells, when the supply of nutrients is disrupted, the cells are malnourished, making them vulnerable to damage. The nicotine content in cigarettes also results in thickening of the walls of blood vessels which aggravates the supply of blood and nutrients to the tissues. One of the final results of cigarettes is carbon monoxide poisonous gas. Carbon monoxide produced from burning cigarettes will bind to hemoglobin $(\mathrm{Hb})$, thereby inhibiting and also reducing the release of oxygen (which should bind to hemoglobin) to the tissues, especially the network of intervertebral disc cells that lack nutrients. In addition, nicotine has a negative effect on osteoblast cells, which affects the proliferation and cellular metabolism of osteoblasts and collagen synthesis, resulting in reduced bone mineral density (Patrianingrum, Meliani., Oktaliansah, Ezra., Surahman, 2015).

When inhaled into the body, the nicotine content in cigarettes affects the activity of two proteins that are related to the process of bone formation. The two proteins are osteoblast and osteoclast. In smokers, osteoclast activity tends to increase while osteoblasts tend to slow down. Bones undergo continuous remodeling through the cycle of destruction and formation. Remodeling is mediated by a balance between osteoclasts that absorb bone and osteoblasts that form new bone. The effect of nicotine on bone cellular is to disturb the balance between bone formation and resorption. Nicotine inhibits the formation of osteoblasts and stimulates the formation of osteoclasts so that the range of bone is damaged (Rocha, 2011).

Pathologically, if there is damage to various tissues and nerve endings, there will be release of chemical mediators and neurotransmitters such as $\mathrm{H}+, \mathrm{K}+, 5-\mathrm{HT}, \mathrm{PG}$, bradykinin, histamine, neuropeptides such as SP, cytokines, purines, eikosanaid and intracellular. This mediator will bind to specific receptors in the peripheral sensory nerve fibers around nerve endings which later through the process of transduction, transmission and modulation will reach the sensory cortex region and are perceived by the brain as pain (Purba, Jan S., Rumawas, 2006)

Pain can cause impairment and disability. Impairment is an abnormality or loss of anatomic, physiological, and psychological functions, while disability is the result of impairment, which is a limitation or disruption of the ability to carry out daily activities.

This pain can limit the work and functional abilities of workers who usually cause a person to retire early from work, especially in jobs that require energy and muscle mobilization (Shonafi K.A, 2012).

\section{KESIMPULAN DAN SARAN}

Based on the results of data analysis from the research conducted, it can be concluded that there is a relationship between the degree of smoking with low back pain disability toward TKBM in the Kendari Port. It is recommended for company researchers to pay attention to the risk factors associated with the occurrence of low back pain, especially on individual factors in order to prevent the occurrence of low back pain for workers. In addition, attention needs to be 
paid for workers' health by registering workers in health insurance in order to receive health insurance in the future. For further researchers it is recommended that research on individual risk factors such as physical activity, occupational risk factors such as work position, workload and environmental risk factors such as vibration

\section{REFERENCES}

Alifariki, L. O. (2015). Analisis Faktor Determinan Proksi Kejadian Hipertensi di Poliklinik Interna BLUD RSU Provinsi Sulawesi Tenggara. Medula, 3(1), 214-223. Retrieve from http://ojs.uho.ac.id/index.php/medula/a rticle/view/2539

Arikunto. (2010). Prosedur Penelitian Suatu Pendekatan Praktik. Jakarta: Rineka Cipta.

Hadyan, M. F. (2015). Faktor - Faktor yang Mempengaruhi Kejadian Low Back Pain pada Pengemudi Transportasi Publik. Jurnal MAJORITY, 4(7), 1924. Retrieved from http://juke.kedokteran.unila.ac.id/index .php/majority/article/view/1442

Helmi, Z. N. (2013). Buku Ajar Gangguan Muskuloskeletal. Jakarta: Salemba Medika.

Hoy, D., March, L. \& Brooks, P. (2014). The global burden of low back pain: estimates from the Global Burden of Disease 2010 study. BMJ Journals, 20, 23-30. Retrieved from https://ard.bmj.com/content/73/6/968

Jalajuwita, P. (2015). hubungan antara posisi kerja dengan keluhan muskuloskeletal pada unit pengelasan PT. X, Bekasi. Airlangga. Retrieved from https://ejournal.unair.ac.id/IJOSH/article/down load/1640/1265\%0APDF

Lincoln, A. E., Smith, G. S., Amoroso, P. J., \& Bell, N. S. (2003). The effect of and noise should be carried out for further research so that they can be compared to see which risk factors are most influential on the occurrence of this low back pain. The researchers suggest that for workers who smoke, it is advisable to stop smoking or reduce cigarette consumption.

cigarette smoking on musculoskeletalrelated disability. American Journal of Industrial Medicine, 43(4), 337-349. https://doi.org/10.1002/ajim.10195

Patrianingrum, Meliani., Oktaliansah, Ezra., Surahman, E. (2015). Prevalensi dan Faktor Resiko Nyeri Punggung Bawah di Lingkungan Kerja Anastesiologi Rumah Sakit Dr. Hasan Sadikin Bandung. Jurnal Anastesi Perioperatif, 3(1), 47-56. Retrieved from http://journal.fk.unpad.ac.id/index.php/ jap/article/view/379

Prasarn, Mark L., Horodyski, Mary B., Behrend, Caleb., Wright, John., Rechtine, G. R. (2012). Negative effects of smoking, workers compensation, and litigation on pain/disability scores for spine patients. International Journal of Neurosurgery And Neurosciences, 3, 366-369. Retrieved from https://www.ncbi.nlm.nih.gov/pubmed/ 23248756

Purba, Jan S., Rumawas, A. M. (2006). Nyeri Punggung Bawah:Studi Epidemiologi, Patofisologi dan Penanggulangan. Jurnal Berkala Neuorsains, 7(2). Retrieved from http://ilib.ugm.ac.id/jurnal/detail.php?dataId= 4707

Riningrum, Hanif., Widowati, E. (2016). Pengaruh Sikap Kerja, Usia, Dan Masa Kerja Terhadap Keluhan Low Back Pain. Jurnal Pena Medika, 6(2), 91- 
102.

Retrieved

from

https://jurnal.unikal.ac.id/index.php/me dika/article/download/394/352

Rocha, M. I. . (2011). Nicotine effects on bone metabolism: in vitro studies with human osteoclasts and co-cultures osteoclasts and osteoblasts in an hydroxyapatite surface. Universitas de Porto, Porto. Retrieved from https://repositorioaberto.up.pt/bitstream/10216/61547/1/ 000148636.pdf

Rohmawan, Eko Arma., Haryono, W. (2017). Masa Kerja, Sikap Kerja Dan Keluhan Low Back Pain Pada Pekerja Bagian Produksi PT Surya Besindo Sakti Serang. In Peran Tenaga Kesehatan dalam Pelaksanaan SDGs. Jakarta: Universias Ahmad Dahlan. Retrieved from http://eprints.uad.ac.id/5393/

Shonafi K.A. (2012). Hubungan Antara Intensitas Nyeri dengan Disabilitas Aktivitas Sehari-hari pada Pasien Nyeri Punggung Bawah (NPB) di RSUD Dr.Moewardi Surakarta. Universitas Muhammadiyah Surakarta. Retrieved from http://eprints.ums.ac.id/18608/9/NASK AH_PUBLIKASI.pdf

Sitepu D.S, Sinaga, L. (2015). Faktor-Faktor Yang Berhubungan dengan Keluhan Low Back Pain Pada Petani Jeruk di Desa Dokan Kecamatan Merek Kabupaten Karo Tahun 2015. Jurnal Lingkungan Dan Kesehatan Kerja, 4(1). Retrieved from https://jurnal.usu.ac.id/index.php/lkk/ar ticle/view/10179/5739

Tveito, T.H., et al. (2004). "Low Back Pain Interventions at the Workplace: A Systematic Literature Review." Occup Med Journal, 54, 3-13. https://doi.org/10.1093/occmed/kqg10 9

WHO Scientific Group. (2003). WHO Technical Report Series 919. The Burden of Musculoskeletal Conditions at the Start of The New Milenium (pp. 1-5). Gevewa: WHO library Cataloguing in Publication Data. Retrieved from https://apps.who.int/iris/bitstream/hand le/10665/42721/WHO_TRS_919 
Jurnal Aisyah: J urnal Ilmu Kesehatan, 4(2), December 2019, - 118

Iriamana Liasyarah Marudin; Muh. Rustam HN; La Ode Alifariki; Adius Kusnan 